\title{
The effects of the Rwandan civil war on poaching of ungulates in the Parc National des Volcans
}

\author{
Andrew J. Plumptre, Jean-Bosco Bizumuremyi, Fidele Uwimana and \\ Jean-Damascene Ndaruhebeye
}

One of the greatest threats that the mountain gorilla Gorilla gorilla beringei faces is the repeated setting of snares for ungulates by people living adjacent to the Parc National des Volcans in Rwanda. Two vets (one expatriate and one Rwandan) are permanently employed to monitor the health of habituated groups of mountain gorillas and to remove snares if an animal becomes caught in one. This study examined how snaring has changed as a result of the Rwandan civil war and how ungulates in the park have been affected. In the region around the Karisoke Research Station ungulate numbers have remained stable and in the case of the black-fronted duiker Cephalophus nigrifrons they have increased at higher altitudes. However, a questionnaire survey among local people showed that there has been a perceived decrease in crop raiding by all ungulates in the west of the park, suggesting a decline in numbers. In the east of the park there appears to have been a decrease in the numbers of black-fronted duikers but an increase in the number of buffaloes Syncerus caffer. The price of bushmeat in real terms has decreased since the war, despite the increase in the price of domestic meat, and poachers interviewed were selling bushmeat more frequently than they did before the war. The level of poaching, therefore, appears to have increased since the war.

\section{Introduction}

The mountain gorilla Gorilla gorilla beringei is known from only two forests, the Virunga volcanoes straddling Zaire (now the Democratic Republic of Congo), Rwanda and Uganda, and the Bwindi Impenetrable forest in Uganda. These two populations are thought to number about 650 animals (McNeilage, 1995). There is some debate about whether the Bwindi population is the same subspecies as the Virunga population (Sarmiento et al., 1996) but this is as yet unresolved. It is thought that the gorillas in the Virunga volcanoes have survived the Rwandan civil war and the subsequent war in Zaire with very few losses attributable directly to the wars. This can only be confirmed with a further census and it is hoped that this will be possible in late 1997.
One of the main threats to the mountain gorillas is the setting of snares to catch antelopes and buffalos in the park. Gorillas caught in these snares may lose a hand or foot, or, more often, die from infection of the wound. In 1986 the Volcanoes Veterinary Centre was established in Rwanda specifically to monitor the health of habituated gorilla groups in the Virungas and to remove snares and treat animals caught in snares. Two vets are currently employed (one expatriate and one Rwandan). This study, which was carried out from June to October 1996, aimed to investigate how ungulate numbers have changed in the Parc National des Volcans (PNV - the Rwandan portion of the Virungas) as a result of the Rwandan civil war and to find out how poaching has changed following the war. The three ungulates found in the park are African 


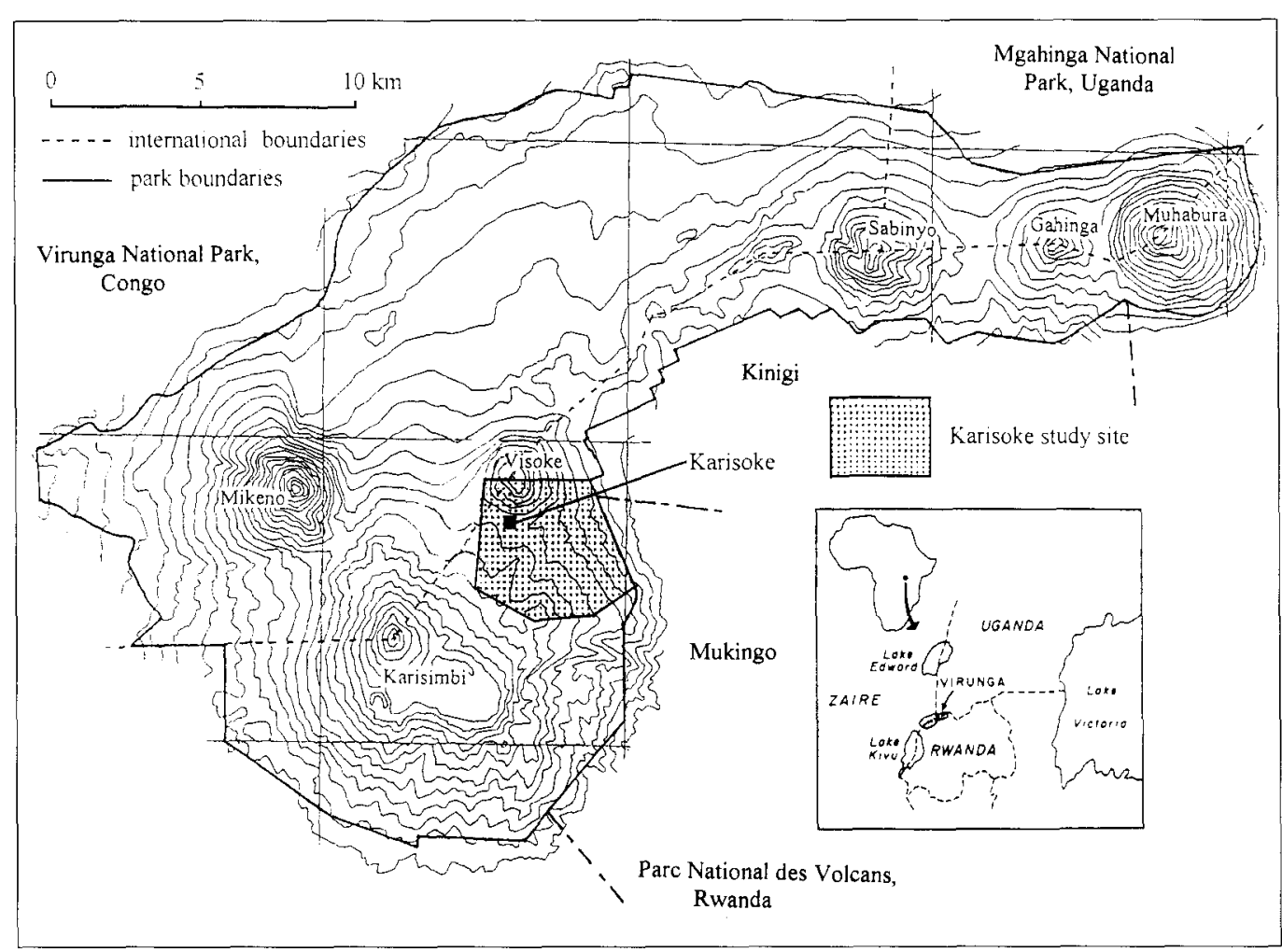

Figure 1. A map of the Virunga volcanos showing the international and park boundaries and the names of the volcanos. The Karisoke study site where the ungulate census was made is shaded and the commune boundaries for Kinigi and Mukingo are marked.

buffalo Syncerus caffer, bushbuck Tragelaphus scriptus, and black-fronted duiker Cephalophus nigrifrons.

\section{The Rwandan civil war}

On 1 October 1990 the Rwandan Patriotic Front (RPF), a mainly Tutsi-dominated force, invaded Rwanda from Uganda. Rwanda at the time was governed by the other major ethnic group in Rwanda, the Hutus. Initially the RPF invaded in the east of the country but was driven back and switched its base to the Virunga volcanoes between Sabinyo and Muhabura (Figure 1). Fighting continued on and off over the next 4 years, the RPF becoming stronger and taking more ground in the north and centre of the country. Several attempts at peace agreements were made but the situation in the country deteriorated and animosity against the Tutsi population was whipped up by Hutu extremists, leading to the genocide that hit the headlines in 1994, and the take-over of the country by the RPF (Prunier, 1995).

During most of the war the staff of the Karisoke Research Station and the park guards continued to patrol the park, often accompanied by the army, looking for poachers and snares. However, this was not possible in the eastern part of the park because the RPF was based there and mines had been laid in and around the park. During July 1994 all the park staff fled to Zaire through the park as the RPF took Ruhengeri and the region around the park. A UN convoy was arranged to bring them back in early August but several of the staff were attacked by interahamwe militias (who did not want people to return to 
Rwanda) while waiting for the convoy to arrive. One of us (J.-B.B.) was taken to hospital with machete and bayonet wounds to the head. Subsequently the staff returned in late August through the park and resumed their duties and the patrolling for snares (Plumptre, 1996). Consequently there was only a short period during the war when the park was not being patrolled. However, life for the staff of the park and of the research station has been very difficult. People frequently accused each other of having taken part in the genocide. Often these accusations were based on truth but occasionally they were made to obtain access to someone's land or house, or to ingratiate themselves with the new government. Many of the park staff and Karisoke staff have been imprisoned and beaten at some point because of accusations made against them but most were released soon afterwards. However, it made the job of finding and arresting poachers more difficult because poachers would often accuse the person arresting them of having been involved in the genocide. It is probable, therefore, that fewer poachers have been arrested since the war than would have been arrested in the past.

\section{Methods}

Two methods were used to measure changes in the ungulate populations. The first involved the recensus of a c. 15-sq- $\mathrm{km}$ area censused between the volcanoes Visoke and Karisimbi (Figure 1) in 1989 (Plumptre, 1991; Plumptre and Harris, 1995), and the second involved the use of a questionnaire survey among the people living around the park.

\section{Recensus of ungulates}

In 1988 and 1989 the three ungulates found in the park (bushbuck, black-fronted duiker and African buffalo) were censused. Faecal counting techniques were used, being the most appropriate technique for the very dense vegetation (Plumptre, 1991; Plumptre and Harris, 1995). Two techniques were used at this time, the standing crop count and the clearance plot count (Staines and Ratcliffe, 1987). In June 1996 the clearance plot count was repeated over 4 months up to the beginning of October. In 1989 twenty $5 \times 10-\mathrm{m}$ plots had been established in eight habitat types (Plumptre, 1991, 1993) giving a total of 160 plots. The habitats were: (i) Bamboo, found at the lowest altitude and dominated by Arundinaria alpina; (ii) Saddle, HageniaHypericum woodland found in the saddle between volcanoes; (iii) Lowland meadow, open meadows below $3100 \mathrm{~m}$; (iv) Herbaceous, areas of dense herbaceous vegetation with no tree cover; (v) Karisimbi meadows, high-altitude meadows above $3100 \mathrm{~m}$ near $\mathrm{Mt}$ Karisimbi; (vi) Brush ridge, Hypericum woodland on the slopes of Mt Visoke; (vii) Giant Lobelia, vegetation dominated by Lobelia stuhlmannii at c. $3400 \mathrm{~m}$; (viii) Alpine, open meadows and Senecio johnstonii above $3500 \mathrm{~m}$. The plots were not randomly placed but were located near paths in the forest so that they could be located easily. In 1996 we attempted to find all the sites of these plots where possible (they had been crudely mapped in 1989) and re-establish them. It was not possible to reach all areas of the study area (Figure 1) because of the proximity to the Zaire border, the need for military escorts and the presence of military ambush points. Two habitats Lowland meadow and Brush ridge - had to be omitted from the analyses because not enough plots were sampled. However, 104 of the plots were located (to within $\pm 20 \mathrm{~m}$ and often more accurately than this) and an additional eight plots established near the park boundary. Plots were visited at approximately 3-week intervals, the pellet groups (for bushbuck and black-fronted duiker) or pats (for buffalo) counted and destroyed or marked with a short stick so that they would not be counted in future. Analyses were compared from the same time period (June to late September) for both studies to avoid any differences that may be due to seasonal use.

\section{Questionnaire survey}

Two people were found (one living near the western side of the park and one in the east) 
who were not employed by the park authorities or by Karisoke Research Station. They were trained to carry out a questionnaire survey among the people living around the PNV. The advantages in using these two research assistants were that they were known locally, they knew who many of the poachers were and could approach people to ask them about illegal activities they might undertake.

Questionnaire surveys give the results of people's perceptions rather than what may actually be happening. The results may also be influenced by what they believe may be a consequence of a particular answer. Each person interviewed was told that his name would not be taken and that none of the questionnaire sheets would be given to any of the park authorities. No promises were made about compensation for crop raiding damage. Not everyone asked was prepared to answer certain questions, particularly those about poaching, and these were recorded as missing values in the analyses. Each assistant walked eight transects perpendicular to the park boundary and interviewed two households in each $500-\mathrm{m}$ distance interval up to $2.5 \mathrm{~km}$ from the park boundary. In addition; they were asked to find and interview anyone they knew to be a poacher. A total of 181 households were interviewed.

\section{Results}

\section{Recensus of ungulates}

Table 1 compares faecal counts in the 104 plots that were re-established from the 1989 count. In most habitats there was no significant

\begin{tabular}{|c|c|c|c|}
\hline Habitat type & $\begin{array}{l}\text { Black-fronted } \\
\text { duiker }\end{array}$ & Bushbuck & $\begin{array}{l}\text { African } \\
\text { buffalo }\end{array}$ \\
\hline All plots & + & NS & NS \\
\hline Bamboo & NS & NS & NS \\
\hline Saddle & NS & NS & NS \\
\hline Herbaceous & NS & NS & NS \\
\hline Karisimbi meadows & NS & NS & NS \\
\hline Giant Lobelia & + & NS & NS \\
\hline Alpine & + & + & NS \\
\hline Near park boundary & NS & NS & NS \\
\hline Away from boundary & + & NS & NS \\
\hline
\end{tabular}

Tests were made using Friedman's ANOVA for all 104 plots and plots in six habitats separately. In addition, plots near the park boundary (within $c .800 \mathrm{~m}$ ) were compared with those further away. + , significant increase at $P<0.05$; NS, not significant

\begin{tabular}{|c|c|c|c|c|c|c|}
\hline \multirow[b]{2}{*}{ Habitat } & \multicolumn{2}{|c|}{$\begin{array}{l}\text { Black-fronted } \\
\text { duiker } \\
\end{array}$} & \multicolumn{2}{|c|}{ Bushbuck } & \multicolumn{2}{|c|}{$\begin{array}{l}\text { African } \\
\text { buffalo }\end{array}$} \\
\hline & 1989 & 1996 & 1989 & 1996 & 1989 & 1996 \\
\hline Bamboo & NS & - & - & - & NS & + \\
\hline Saddle & + & + & + & NS & NS & - \\
\hline Herbaceous & - & - & NS & + & - & - \\
\hline Karisimbi meadows & NS & - & - & - & + & + \\
\hline Giant Lobelia & - & - & - & NS & - & - \\
\hline Alpine & - & - & - & NS & - & NS \\
\hline
\end{tabular}

+ , preference; -, avoidance; NS, no selection

Preferences calculated using the Bonferroni Z statistic (Neu et al., 1974).

Table 1. Differences between faecal pellet counts from 1989 and 1996

Table 2. Habitat preferences for 1989 and 1996 
Table 3. Crop raiding

frequencies (no. days per year) of three ungulates within $500 \mathrm{~m}$ of the park boundary

\begin{tabular}{|c|c|c|c|c|c|c|}
\hline Species & Period & $\begin{array}{l}\text { All data } \\
(n=35)\end{array}$ & $\begin{array}{l}\text { Wes } \\
(n=\end{array}$ & $\begin{array}{l}\text { 18) } \\
\text { 18) park }\end{array}$ & $\begin{array}{l}\text { East } \\
(n=1\end{array}$ & $\begin{array}{l}\text { of park } \\
17)\end{array}$ \\
\hline \multirow{2}{*}{$\begin{array}{l}\text { African } \\
\text { buffalo }\end{array}$} & Before war & 193 NS & 209 & ** & 175 & ** \\
\hline & After war & 208 & 72 & & 353 & \\
\hline \multirow[t]{2}{*}{ Bushbuck } & Before war & $275^{* *}$ & 268 & ** & 283 & NS \\
\hline & After war & 163 & 151 & & 176 & \\
\hline \multirow{2}{*}{$\begin{array}{l}\text { Black-fronted } \\
\text { duiker }\end{array}$} & Before war & $181 *$ & 106 & $*$ & 261 & $*$ \\
\hline & After war & 87 & 44 & & 132 & \\
\hline
\end{tabular}

Wilcoxon's signed ranks tests were used to detect differences significant at $P<0.05$.

The data were also separated by region (east $v s$ west of the park).

${ }^{*} P=0.05 ;{ }^{* *} P<0.01 ; \mathrm{NS}$, not significantly different. change in counts but for the bushbuck and black-fronted duiker there were increased counts at high altitude on the summit of Visoke. The duikers increased in density in the Alpine and Giant Lobelia zones while the bushbuck increased in the Alpine zone. This may be partly due to the army being based at the time at Karisoke and on the slopes of Visoke above the research station and it is probable that the antelopes moved up the mountain to avoid this area. In addition, an increased number of pellets of the black-fronted duiker were found away from the park boundary (most snares are set near the boundary where bamboo is available to use in snare construction). Table 2 shows the habitat preferences of the three species of ungulate recorded, calculated using the Bonferroni $Z$ statistic (Neu et al., 1974) and the changes that have occurred in preference.

\section{Questionnaire survey}

1 Frequency of crop raiding. Households within $500 \mathrm{~m}$ of the park were asked how often each ungulate species moved out of the park and entered their fields. Responses were given as number of times per week/month and were converted to number of days per year. Table 3 gives the mean frequencies of crop raiding before and after the war as perceived by households near the western and eastern parts of the park. In the west ungulates entered fields on significantly fewer days per year than before the war. In the east crop-raiding activities by buffalo increased, bushbuck showed no significant change and raids by black-fronted duikers decreased.

2 Involvement in hunting. Households were asked if they killed animals raiding crops or in the park. They were also asked if they had ever bought bushmeat. Of the total number of households 28.7 per cent said they killed animals on their farms and 11 per cent ( 20 people) admitted to poaching in the park (this is likely to be on the high side because poachers were targeted where they were known), while 33.1 per cent admitted to buying bushmeat at some time. Figure 2 shows the frequencies of buying bushmeat, before, during and after the war. Although there is a perceived drop in frequency after the war, this may be because people did not want to admit to buying meat at present. A Friedman's ANOVA of the combined data showed there were significant differences between periods $\left(\chi^{2}=7.23\right.$, d.f. $\left.=2, P<0.05\right)$.

3 Price of bushmeat. Figure 3 shows the price of bushmeat in Rwanda francs, corrected to prewar prices to take into account inflation. There has been a significant drop in price for each ungulate (Friedman's Anova, $P<0.001$ ). At the same time there has been a significant increase in the price of domestic meat for beef, mutton and goat $(P<0.001)$ following the war because many animals died during the war or were stolen.

4 Poaching effort and success. The 20 people who admitted to poaching in the park were asked how often they entered the park before 

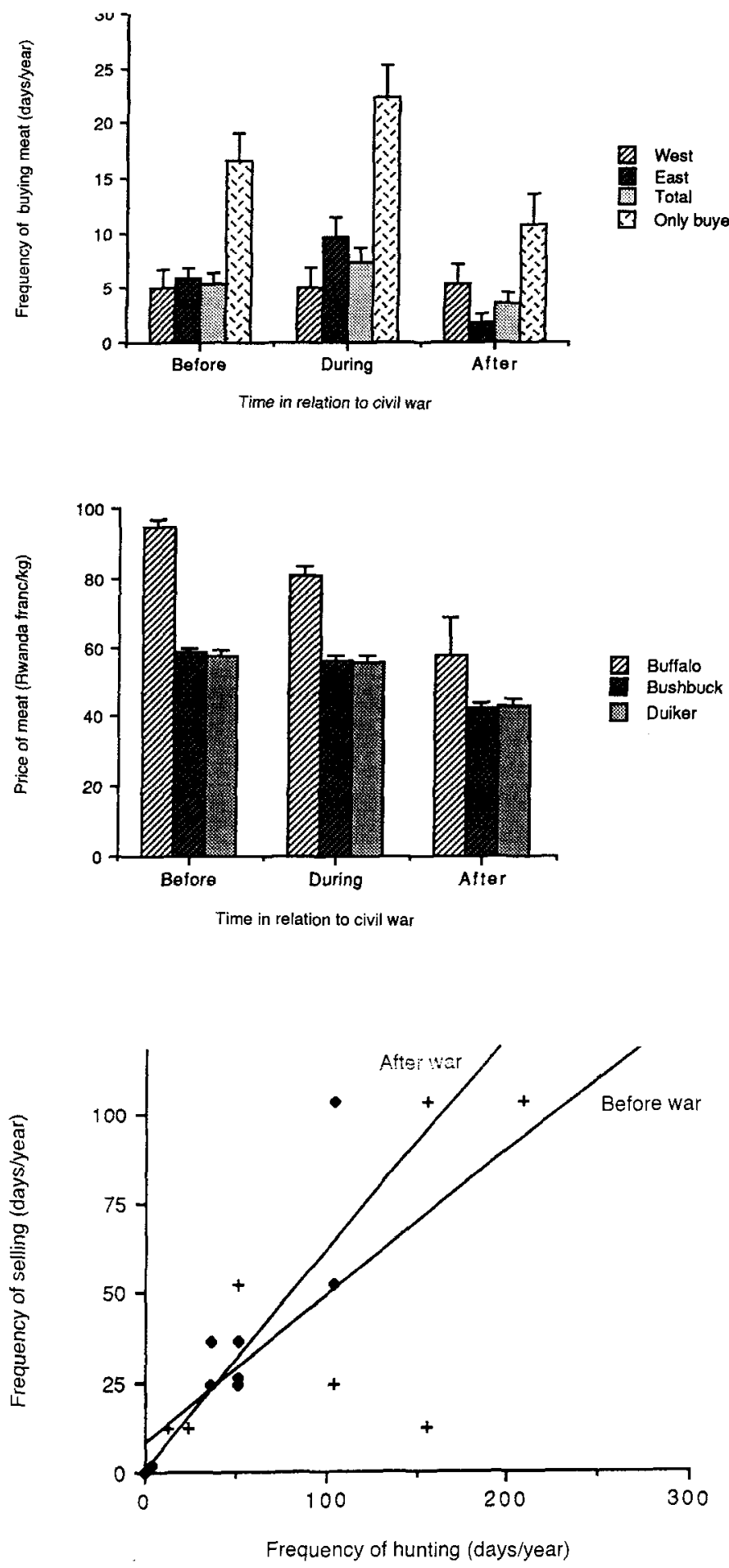

Figure 2. The mean frequency with which people admitted to buying bushmeat in relation to the civil war. The data are separated into those people living near the west and east of the park, the combined data for all people interviewed (total) and the data only for those who admitted buying. The first three means include people who denied ever buying bushmeat and therefore give an indication of days it was purchased on average for the population as a whole in each region. Standard error bars are plotted.

Figure 3. The change in price of bushmeat in Rwanda francs (corrected for inflation) per $\mathrm{kg}$ over the period of the civil war. Standard error bars are plotted.

Figure 4. The frequency of selling bushmeat caught in the park plotted against the frequency of entering the park. Data from before and after the war are plotted separately; + , before the war; $\bullet$, after the war.

(C) $1997 \mathrm{FFI}$, Oryx, 31 (4), 265-273 


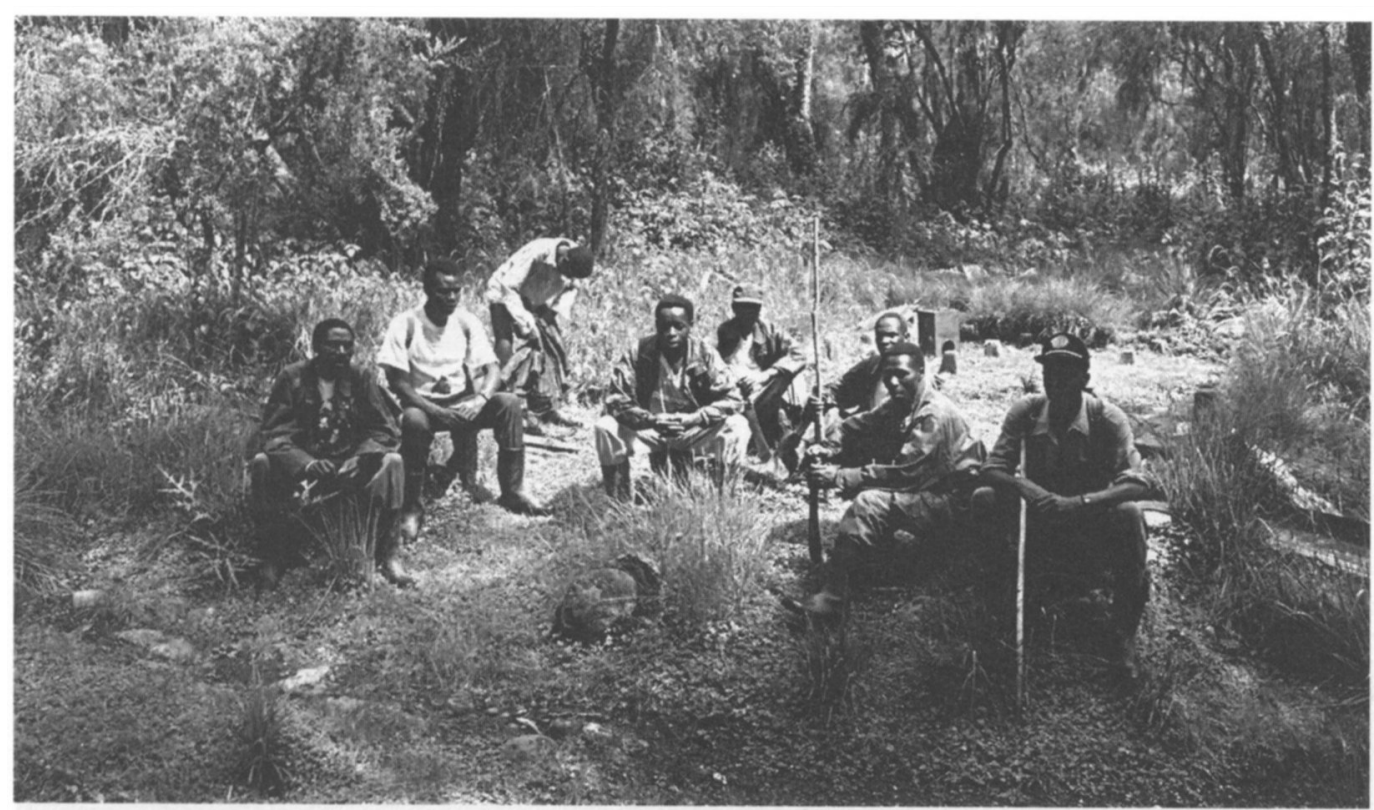

Antipoaching patrol at what remains of one of the houses at Karisoke Research Centre (A. J. Plumptre).

and after the war and how often they sold bushmeat. Figure 4 shows the regressions between frequency of entering the park and frequency of selling meat. Both regressions were significant (before war: $R^{2}=0.67, P<0.001$; after war: $\left.R^{2}=0.77, P<0.001\right)$ and the slopes of the two lines differ significantly $(t=2.42, P$ $<0.05)$. Before the war a poacher sold meat 41 per cent of the times that he entered the park; after the war he sold 61 per cent of the times he entered the park. This may be because he used to consume more at home in the past because it was risky selling it or it could mean that capture rates are higher now than they used to be.

\section{Discussion}

Questionnaire surveys should always be analysed with caution because people's perception of events changes with the time that has elapsed since the event. However, this study was based upon a reasonable sample size (181 households) and the majority of respondents in the same region concurred about increases or decreases in animal numbers. The results presented here indicate that, despite the finding that there has been no decrease in the ungulate populations around Karisoke, there has probably been a decrease when the whole of the western part of the park is looked at (based on the decrease in crop-raiding activity). This decrease in crop raiding was not likely to be due to any differences in crops being grown because these were similar to those grown before the war (potatoes, wheat and sorghum), and by June 1996 the fields were full of crops. In the east, where the RPF was based during the war, crop-raiding evidence indicates that the buffalo population has increased. This is highly possible because poachers interviewed stated that they did not enter this area during the war but are now favouring it because antelope numbers are relatively high. The numbers of snares being removed by Karisoke staff are high at present, although the number of snares found per working day peaked in 1992 and 1993 according to records made by Karisoke Research Station (N. Fitzgerald pers. comm.). In addition, the presence of the army in the park was leading to poaching incidents (one buffalo was killed during this study by the army; 


\section{A. J. PLUMPTRE ET AL.}

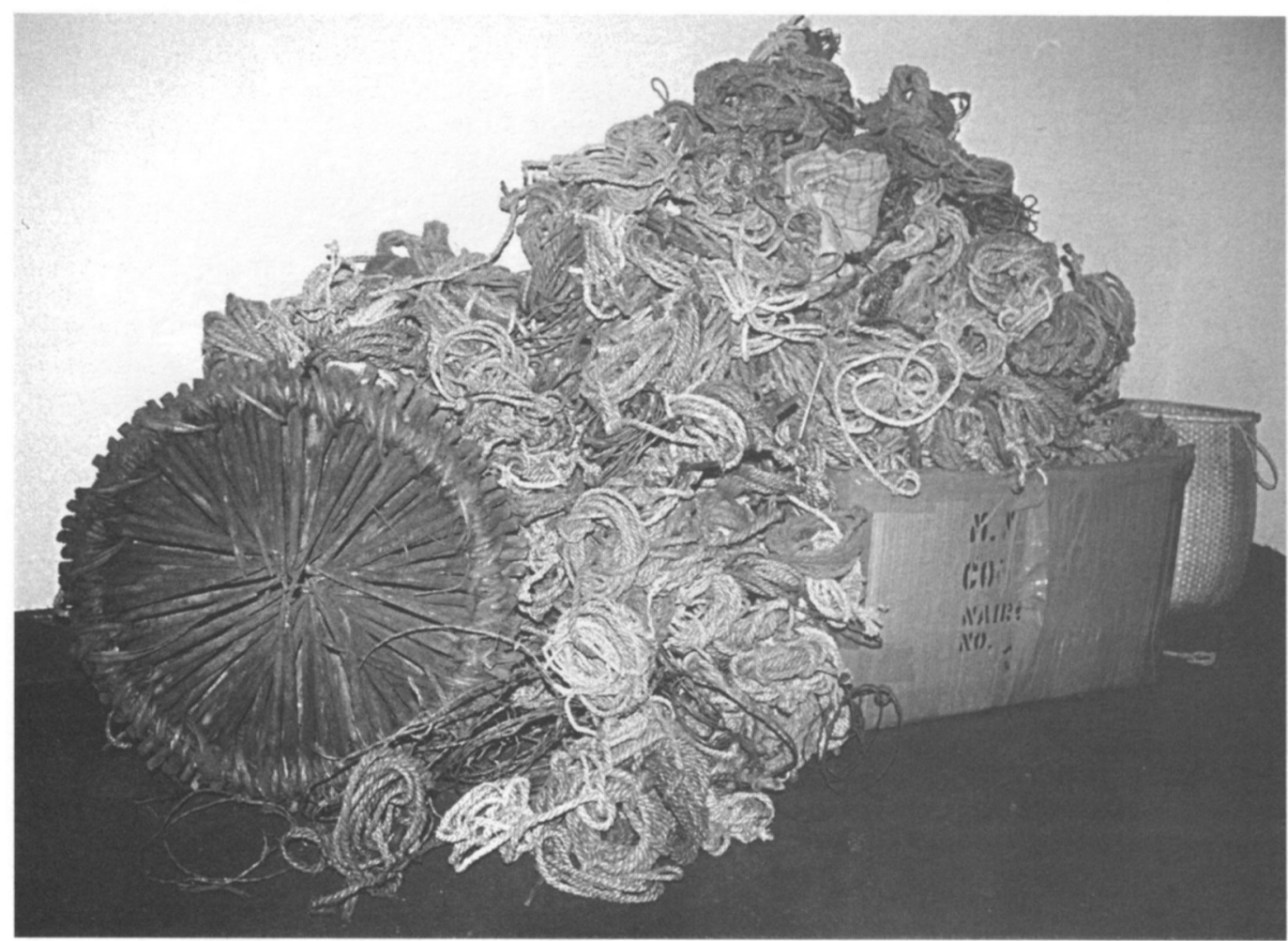

Snares collected during 1996. The large circular snare on the left is for buffalo (A. J. Plumptre).

A. Plumptre pers. obs.). Since the return of the refugees in November 1996 poaching has increased further (J. B. Bizumuremyi, pers. obs.) because many of the Batwa have now returned. The Batwa are traditional forest people who hunt with bows and arrows in the forest. However, the relative peace that now exists in Democratic Republic of Congo near the park as a result of the destruction of the refugee camps means that the army personnel are no longer needed to patrol the park border and they have left.

The fact that bushmeat is cheaper in real terms than it used to be, despite the fact that domestic meat is more expensive, implies that there is probably more of it on the market and this is supported by the finding that poachers are selling more meat per unit effort of hunting (Figure 4). It is concluded, therefore, that poaching increased during and following the war, particularly in the west of the park, leading to a decline in ungulate numbers. Around
Karisoke Research Station, however, the numbers of ungulates have not changed much since 1989 (Plumptre and Harris, 1995).

\section{Conclusions}

It is important for the conservation of the mountain gorilla that snares continue to be found and removed. Snare removal is fairly effective around the Karisoke Research Station because of the manpower and support it receives. The Park Conservateur has many issues to deal with besides antipoaching patrols. Army personnel have been harvesting bamboo and firewood from the park illegally and selling it, and consequently the local people have started to do the same. Gradually the situation is improving and army staff have been reprimanded for carrying out illegal poaching and have returned stolen park property. Ultimately, the protection of the park and the 
future of the mountain gorilla and the other wildlife requires a restoration of law and order in Rwanda and the Democratic Republic of Congo, and a return to peace.

\section{Postscript}

This article was written in January 1997 and since that time the security situation in Rwanda has deteriorated markedly. In April it is estimated that at least 2000 members of the interahamwe and old army entered the Virunga volcanoes, joining smaller parties that had been entering from late January. These people have been coming out of the forest at night, killing people working with the government and witnesses to genocide incidents. The Assistant Park Warden of the Parc National des Volcans was assassinated in May and it is now considered too dangerous to patrol the forest for snares. Four mountain gorillas were shot in June as soldiers of the Democratic Republic of Congo were trying to flush out these militias. It is known that these infiltrators are living off bushmeat in the forest; one man recently surrendered and admitted to living on bushmeat for the past 2 weeks.

In August 1997 the Office Rwandais de Tourisme et Parcs Nationaux suspended activities in the Parc National des Volcans because of the insecurity and consequent danger to the lives of their personnel.

\section{Acknowledgements}

This study was funded by the Wildlife Conservation Society/New York Zoological Society and builds upon a study funded in $1988 / 89$ by Bristol University, The Fauna \& Flora Preservation Society and the Dian Fossey Gorilla Fund - we are grateful for all their support. We are also grateful to: Office Rwandais de Tourisme et Parcs Nationaux (ORTPN); the Conservateur of the PNV, M. J. Rurangirwa-Nyampeta; and the Karisoke Research Station and its director Dr E. Williamson for permission to work in the park and their support for this work. We also want to thank the Bourgmestres of Kinigi and Mukingo for their permissions to carry out the questionnaire survey. François-Xavier Ngarukiyintwari and Leonidas Ngaboyisonga car- ried out the surveys very efficiently and competently. Finally, we would like to thank Oxford University for the use of facilities at the Institute of Biological Anthropology.

\section{References}

Neu, C.W., Byers, C.R., Peek, J.M. and Boy, V. 1974. A technique for analysis of utilisation-availability data. Journal of Wildlife Management, 38, 541-545.

McNeilage, A.J. 1995. Mountain gorillas in the Virunga volcanos: ecology and carrying capacity. $\mathrm{PhD}$ thesis, University of Bristol.

Plumptre, A.J. 1991. Plant herbivore dynamics in the Birungas. PhD thesis, University of Bristol.

Plumptre, A.J. 1993. The effects of trampling damage by herbivores on the vegetation of the Parc National des Volcans, Rwanda. African Journal of Ecology, 32, 115-129.

Plumptre, A.J. 1996. Gorilla War: the human cost of protecting Rwanda's mountain gorillas. Swara, 19, 30-31.

Plumptre, A.J. and Harris, S. 1995. Estimating the biomass of large mammalian herbivores in a tropical montane forest: a method of faecal counting that avoids assuming a 'steady state' system. Journal of Applied Ecology, 32, 111-120.

Prunier, G. 1995. The Rwanda Crisis 1959-1994. History of a Genocide. Fountain Publishers, Kampala, Uganda.

Sarmiento, E.E., Butynski, T.B. and Kalina, J. 1996. Gorillas of Bwindi Impenetrable Forest and the Virunga Volcanoes: taxonomic implications of morphological and ecological differences. American Journal of Primatology, 40, 1-21.

Staines, B.W. and Ratcliffe, P.R. 1987. Estimating the abundance of red deer (Cervus elaphus L.) and roe deer (Capreolus capreolus L.) and their current status in Great Britain. Symposium of the Zoological Society of London, 58, 131-152.

Andrew J. Plumptre, Institute of Biological Anthropology, University of Oxford, 58 Banbury Road, Oxford, UK. Current address: Wildlife Conservation Society, 185th Street and Southern Boulevard, Bronx, NY 10460, USA.

Jean-Bosco Bizumuremyi, Karisoke Research Centre, BP 105, Ruhengeri, Rwanda.

Fidele Uwimana, Karisoke Research Centre, BP 105, Ruhengeri, Rwanda.

Jean-Damascene Ndaruhebeye, Karisoke Research Centre, BP 105, Ruhengeri, Rwanda. 